\title{
The Impact of Climate Change and Human Activity on Net Primary Production in Tibet
}

\author{
Xiaojing Qin ${ }^{1,4}$, Jian Sun², Miao Liu ${ }^{3}$, Xuyang Lu ${ }^{1}$ \\ 'Institute of Mountain Hazards and Environment, Chinese Academy of Science, Chengdu 610041 \\ ${ }^{2}$ Key Laboratory of Ecosystem Network Observation and Modeling, Institute of Geographic Sciences and Natural \\ Resources Research, Chinese Academy of Sciences, Beijing 100101, China \\ ${ }^{3}$ State Key Laboratory of Urban and Regional Ecology, Research Center for Eco-environmental Sciences, \\ Chinese Academy of Sciences, Beijing 100085, China \\ ${ }^{4}$ University of Chinese Academy of Sciences, Beijing 100049, China
}

Received: 23 February 2016

Accepted: 2 May 2016

\begin{abstract}
The Tibetan Plateau has faced environmental degradation in recent years due to intensified human activity and climate change. In this study, the dynamics of net primary production (NPP), annual mean temperature (AMT), annual mean precipitation (AMP), number of animals (NA), number of rural laborers (NRL), and animal husbandry (AH) were analyzed and the response of NPP to climate and human activity explored. The results show that NPP was increasing gradually from northwest to southeast and is similar to the distribution of AMP. In addition, NA, NRL, and AH cluster around Lhasa. Moreover, AMP had a negative correlation with NPP in Tibet while AMT has a positive effect on NPP. Moreover, because of the large number of livestock there is a negative relationship between NA and NPP in most Tibetan regions. Furthermore, it was found that human activity made a higher contribution to NPP in Tibet $(24.73 \%)$ than climate factors $(17.28 \%)$. It is, therefore, necessary to further explore the relationship between human activity and the vegetation dynamic in the region.
\end{abstract}

Keywords: NPP, climate change, human activity, Tibet, Tibetan Plateau

\section{Introduction}

It is undeniable that average annual global temperatures have increased [1]. In many parts of the world, ecological systems have been influenced by rising temperatures. For example, one reason for the change in lake areas is permafrost degradation, which is caused by a warming

*e-mail: sunjian@igsnrr.ac.cn climate. Indeed, there is concern about vegetation because it is an integral part of grassland systems. Exploring the responses of vegetation to climate change is urgently needed.

Generally, grassland is an important indication of carbon circulation in the soil surface and vegetation [2]. In recent years, net primary production (NPP) was defined as the greatest annual carbon circulation between the atmosphere and the biosphere [3], which is a good indicator for evaluating the energy or biomass of the 
grassland ecosystem. In China's temperate grassland, vegetation productivity showed an increasing trend from the 1980s through the 1990s as temperatures increased [4]. In addition, vegetation may respond to sudden climate change. Nevertheless, researchers have different points of view regarding the effects of temperature and precipitation on vegetation dynamics. In the northwestern Loess Plateau, for example, the relationship between rising temperatures and vegetation degradation was negative [5]. On the other hand, the degradation of vegetation is expected to decrease under current climate-trend conditions in Inner Mongolia [6]. Earlier studies have suggested that precipitation has played the most important role for vegetation dynamics, indicating that vegetation is more sensitive to precipitation than to temperature [7]. However, environmental factors such as temperature and precipitation affect vegetation hybrids to a certain extent, and both are analyzed in this paper.

As the most sensitive area in the world to environmental change [8], the Tibetan Plateau has received considerable attention in terms of responses to climate factors. Many studies have focused on the dynamic distribution of vegetation NPP and the responses to climate factors $[9,10]$. In Tibet, the NPP decreased from southeast to northwest $[11,12]$ due to the different vegetation types [13]. As the research shows, the vegetation NPP responded to annual average temperature and annual precipitation in the Tibetan Plateau. Indeed, the variation of NPP may be influenced by humans through the presence of grazing $[14,15]$. Moreover, the Tibet Autonomous Region hosts one of the world's largest pastoral ecosystems [16-19]. However, human activity and its effect on vegetation dynamics under the impact of climate change should not be ignored [20], as the vegetation often serves as the primary source of livelihood in many regions [21]. Population expansion and overgrazing may be the cause of the variation in vegetation. While previous studies have focused on the dynamics of climate and vegetation indices and the relationships between them, understanding the long-term interactions of vegetation, climate, and human activity is vital.

Against this background, the present study was undertaken with the following objectives: (a) to explore the spatial-temporal variation in vegetation NPP, temperature, precipitation, the number of animals at yearend (NA), number of rural laborers (NRL), and animal husbandry $(\mathrm{AH})$; (b) to analyze the relationship between NPP, climate, and human activity, and to calculate the impact (as a percentage) of each.

\section{Materials and Methods}

\section{Study Area}

The Tibet Autonomous Region $\left(26^{\circ} 44^{\prime}-36^{\circ} 32^{\prime} \mathrm{N}\right.$, $\left.78^{\circ} 25^{\prime}-99^{\circ} 06^{\prime} \mathrm{E}\right)$ is located in northwestern China at an average elevation of $4,730 \mathrm{~m}$ (Fig. 1). The total land area is more than 1.23 million $\mathrm{km}^{2}$ and covers $47.9 \%$ of the total

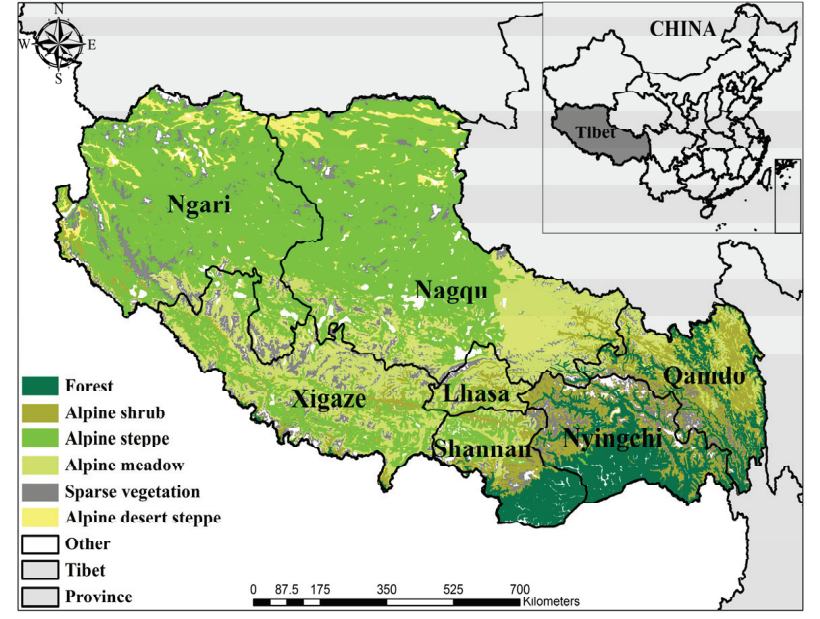

Fig. 1. Spatial distribution of vegetation in the study area.

area of the Tibetan Plateau. The annual mean precipitation (AMP) of Tibet is approximately $358 \mathrm{~mm}$, and the annual mean temperature (AMT) is $4.2^{\circ} \mathrm{C}$ for the period 19822013. Most precipitation falls as rain during the summer months (May-September), which accounts for $90 \%$ of AMP. The region is mainly comprised of alpine steppe and alpine meadow, and the most important ecosystem is alpine grassland [1, 22-24]. Vegetation types range from forest in the southeast to grassland in the northwest. Moreover, animal breeding is the principal source of income.

\section{Data Pre-Handling and Methods}

The annual NPP was downloaded from MODIS global data set (MOD17) at an 8-km resolution from 2000 to 2012. The NPP product was the first satellite-driven dataset to monitor vegetation productivity based on the NASA Earth Observation System (EOS) program.

Meteorological data used in this study were collected from the Meteorology Information Center of the Chinese National Bureau of Meteorology, which includes annual mean temperature and total precipitation collected from 39 meteorology observatories during 2000-12. AMT and AMP were acquired, and the Kriging interpolation method was used to show spatial distribution patterns.

In terms of NPP, the number of livestock has a direct impact on vegetation, and most rural people grazed their livestock. Thus the number of laborers determined the number of animals. At the same time, the quality of animal husbandry mirrors the level of economic development as a whole (apart from livestock income, which might show an indirect influence on NPP). The humanistic economic data stems from the Tibet Statistical Yearbook and include the number of animals (NA) at year-end, the number of rural laborers (NRL), and information about animal husbandry (AH) in every county from 2000-12. In this study, the average values of the three indicators for this period were used to compare differences on a spatial scale.

To analyze the effects of human activity on vegetation, this study made a correlation analysis at the county 
scale. Pearson correlation index was used to present the coefficient level between climate, human activity, and NPP (the range is -1 to 1 ). The more absolute value trends to be 1 (the higher relationship). Following the test, dates used in this paper conform to the hypotheses as follows: there is a line correlation between two variations and both are successive; moreover, the independent variations agree with the Gaussian distribution. In addition, Student's test estimated the significance of correlation, and 0.05 and 0.01 are the inspection standard (significant and extremely significant, respectively). As a result, the correlation coefficient indicates the close degree of relationship. The correlation coefficient $p<0.05$ represented a significant correlation, while $p<0.01$ was indicative of an extremely significant correlation. The influence of climate and human activity were each examined accordingly. In addition, the contributions of climate change and human activity to NPP were calculated in R software. Redundancy analysis (RDA) was used to explore the influence on NPP, then expressed by Venn figures. The analysis operations mentioned above were realized using ArcGIS 9.3 (ESRI, Inc., Redlands, CA, USA), SigmaPlot for Windows version 10.0 (Systat Software, Inc., Chicago, IL, USA), and R Core Team (R: A language and environment for statistical computing. R Foundation for Statistical Computing, Vienna, Austria (www.R-project.org).

\section{Results and Discussion}

\section{Geographic Distribution of NPP, AMT, AMP, NA, NRL, and AH in Tibet}

Averaged annual NPP and NPP values for each vegetation type are shown in Table 1 across Tibet from 2000-12. The 13-year mean annual NPP and averaged total annual NPP were 1,492.563 $\mathrm{g} \mathrm{C} \mathrm{m}^{-2} \mathrm{a}^{-1}$ and $19,403.323 \mathrm{~g} \mathrm{C} \mathrm{m}^{-2} \mathrm{a}^{-1}$, respectively.

Alpine steppe, meadow, and desert steppe are the three biome types, with the alpine steppe and meadow occupying most of the area (Fig. 1). The largest mean NPP appeared in the forest ecosystem $\left(598.807 \mathrm{~g} \mathrm{C} \mathrm{m}^{-2}\right.$ $\left.\mathrm{a}^{-1}\right)$, followed by cultivated land (569.632 $\left.\mathrm{g} \mathrm{C} \mathrm{m}^{-2} \mathrm{a}^{-1}\right)$, alpine shrub (195.013 g C m $\mathrm{g} \mathrm{a}^{-1}$ ), alpine meadow
(83.853 $\left.\mathrm{g} \mathrm{C} \mathrm{m}^{-2} \mathrm{a}^{-1}\right)$, and alpine steppe (26.846 $\left.\mathrm{g} \mathrm{C} \mathrm{m}^{-2} \mathrm{a}^{-1}\right)$, with alpine desert steppe having the smallest NPP value (18.411 $\left.\mathrm{g} \mathrm{C} \mathrm{m}^{-2} \mathrm{a}^{-1}\right)$. Total forest NPP recorded the largest percentage $(40.1 \%)$ of the area in Tibet, while alpine steppe, meadow, and desert steppe accounted for only $1.8 \%, 5.6 \%$, and $1.2 \%$, respectively.

Based on vegetation type, NPP significantly decreased from northwest to southeast (Fig. 2a) and was consistent with the change of annual mean precipitation (Fig. 2c), but not with annual mean temperature (Fig. 2b). NPP in the northwestern areas generally varied from 14 to $265 \mathrm{~g} \mathrm{C} \mathrm{m}^{-2} \mathrm{a}^{-1}$ where alpine and meadow are distributed. In northern Tibet, the annual mean temperature was $-1.6-3.5^{\circ} \mathrm{C}$ lower than in other zones. Moreover, the density of NA, NAL, and AH show the "gather phenomenon," which is not balanced in temporal scale (Figs. 2d-2f). As for NA and NAL, we found animals and rural laborers with $0.5-17$ head $^{-1}$ and $0.06-1$ people per $\mathrm{km}^{2}$ in Nyingchi, Ngari and north of Nagqu, Xigaze, respectively. The gather zones were Lhasa and surrounding areas. Similarly, $\mathrm{AH}$ also decreased gradually from Lhasa to its environs, apart from eastern Qamdo.

As the results have demonstrated, the NPP of the Tibetan Plateau was increasing although it is likely that the average net primary productivity would decrease in China with a warming climate [25]. Nevertheless, the distribution of NPP and annual mean temperature were similar at the temporal scale, which indicates a strong relationship between NPP and temperature. We also know that annual mean precipitation is increasing from northwest to southeast, and similar herds exhibited with NPP. In addition, a tendency toward warming and increased moisture can be identified across the Tibetan Plateau over past decades. Generally, temperature increases were higher in eastern regions than in western regions, and precipitation increased gradually from southern to northern Tibet. Annual precipitation presented an increasing trend across the Tibetan Plateau [26], but the growing trend ceased until 2000 in Tibet.

In fact, NPP is the accumulation of organic matter made by plants in a unit zone and time. In other words, the variation of NPP represents the dynamic of vegetation. Many researchers report that the areas of vegetation degradation increased in recent years, especially in

Table 1 . Annual net primary production (NPP) for different vegetation types in Tibet.

\begin{tabular}{|c|c|c|c|c|}
\hline Vegetation type & Area $\left(10^{4} \mathrm{~km}^{2}\right)$ & $\mathrm{NPP}\left(\mathrm{g} \mathrm{C} \mathrm{m}^{-2} \mathrm{a}^{-1}\right)$ & $\mathrm{SD}$ & Total NPP $\left(\mathrm{g} \mathrm{C} \mathrm{m}^{-2} \mathrm{a}^{-1}\right)$ \\
\hline Forest & 0.82 & 598.81 & 439.11 & $7,784.50$ \\
\hline Alpine steppe & 51.54 & 26.85 & 42.69 & 349.00 \\
\hline Alpine meadow & 27.43 & 83.85 & 65.59 & $1,090.09$ \\
\hline Alpine desert steppe & 6.20 & 18.41 & 24.61 & 239.35 \\
\hline Alpine shrub & 12.33 & 195.01 & 148.70 & $2,535.16$ \\
\hline Cultivation & 0.82 & 569.63 & 477.81 & $7,405.22$ \\
\hline Total & 99.13 & $1,492.56$ & $1,198.51$ & $19,403.32$ \\
\hline
\end{tabular}




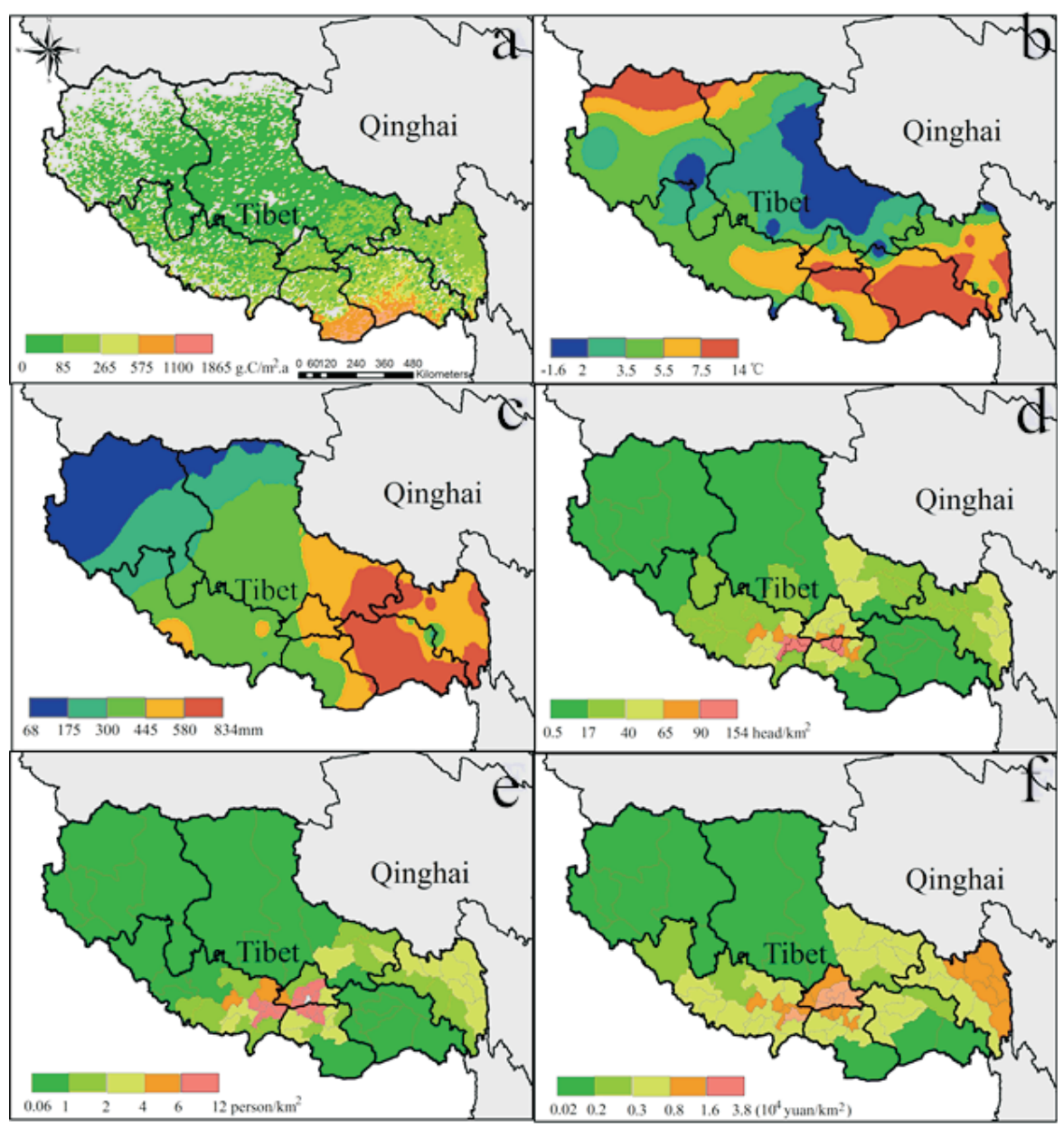

Fig. 2. Distribution of NPP a), AMT b), AMP c), NA d), NRL e), and AH f) in the study area.

northwestern [27, 28] and southeastern Tibet. Hence the vegetation is also influenced by human activity and climate factors - especially in recent years when economic development and city growth has been rapid. As a consequence, the imbalance phenomenon of NA, NRL, and $\mathrm{AH}$ is significant, which regards Lhasa as the center, and decreased gradually in surrounding regions. Thus the impact of human activity on the production of vegetation would alter the circulation of the ecosystem.

\section{The Changing Trends of NPP, AMT, AMP, NA, $\mathrm{NRL}$, and $\mathrm{AH}$ in Tibet}

Fig. 3a illustrates that annual NPP varied from 251.13 $\mathrm{g} \mathrm{C} \mathrm{m}^{-2} \mathrm{a}^{-1}$ to $306.15 \mathrm{~g} \mathrm{C} \mathrm{m}^{-2} \mathrm{a}^{-1}$, showing an increase rate of 3.03 per year between 2000 and $2012\left(R^{2}=0.477\right.$, $p<0.01)$. The dynamic trends of annual mean temperature and annual mean precipitation were analyzed between 1982 and 2013 (Figs 3b, 3c). There has been a significant trend in AMT $\left(R^{2}=0.683, p<0.001\right)$ by $1.82^{\circ} \mathrm{C}$ in the past 32 years. On the other hand, a declining trend began in 2000 in terms of AMP $\left(R^{2}=0.171, p<0.001\right)$, recording a decrease of approximately $8 \mathrm{~mm}$, which is cause for concern. In recent years, the number of animals at year-end has plummeted (Fig. 3d). From 2000 to 2012,
NA showed a cubic variation with the largest value of $24.3910^{6} \mathrm{head}^{-1}$ in $2004\left(R^{2}=0.844, p<0.01\right)$. Figs $3 \mathrm{e}$ and $3 \mathrm{f}$ show a significant increase in NRL and $\mathrm{AH}\left(R^{2}=0.997\right.$, $p<0.01$ and $R^{2}=0.993, p<0.01$ ). During 2000-12, the $\mathrm{NRL}$ and AH increased dramatically from $100.4110^{4}$ to $127.3110^{4}$ and $2,247.0210^{6}$ to $5,857.1410^{6}$, respectively.

Our results suggest that the NPP presented an increasing trend in the study area from 2000 to 2012, as it does on the Tibetan Plateau [29]. Globally, over the past 150 years, the mean temperature has risen by $0.4^{\circ} \mathrm{C}[30]$, and by $1.8^{\circ} \mathrm{C}$ over the past 32 years in Tibet, while the trend in annual mean precipitation has decreased since 2000. The increases in rural labor have led to an increase in the consumption of natural resources [31]. Although the number of livestock has decreased, this does not indicate a corresponding decrease in influence from human activity on vegetation. In some of the world's metropolises, vegetation degradation would not necessarily result from urbanization because of improved environmental quality [32]. However, in Tibet, where there is a fragile ecosystem [33], the increased population may bring decreased grassland, and a decline in the number of animals means less pressure from large-scale overgrazing. 

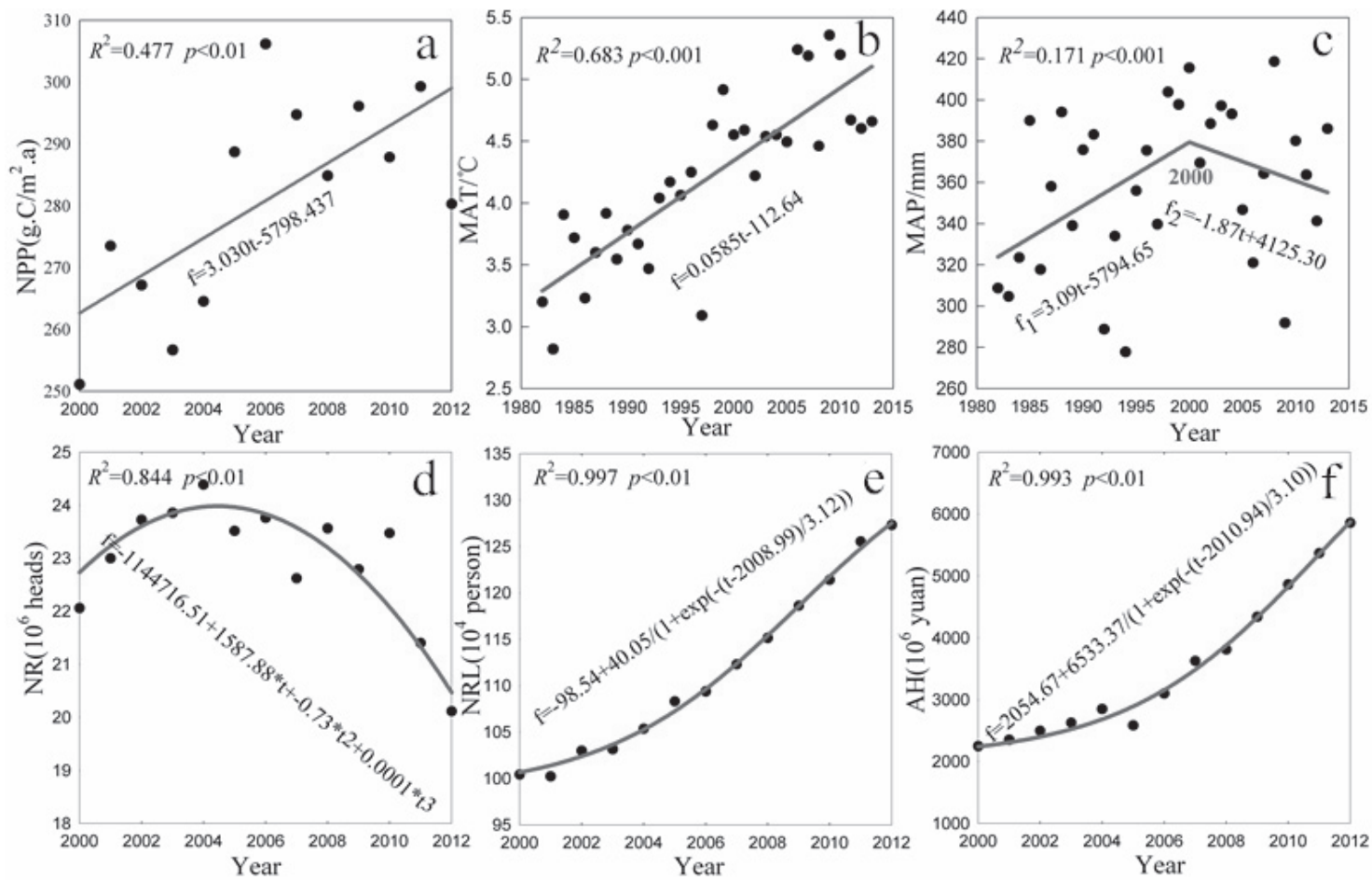

Fig. 3. Change trends of NPP a), AMT b), AMP c), NA d), NRL e), and AH f) in Tibet.

\section{Relationship between NPP and Climate/Human Activity Factors in Tibet}

From Fig. 2, the distribution of animals is not balanced across Tibet. In Table 2, the results show that AMT, AMP, and NRL have significant positive relationships with NPP in Tibet $(p<0.05)$. Nevertheless, there is a negative correlation between AMP and NPP in Shannan and Nyingchi. Table 2 shows that only climate factors have a relatively significant impact on the inter-annual variation in NPP in Lhasa. However, these results indicate that the correlation between NRL, NA, and NPP are extremely significant $(p<0.01)$ with multiple $R^{2}$ values of 0.747 and 0.779 in Nagqu and Nyingchi, respectively. For the Qando region, AMT $\left(R^{2}=0.701, p<0.01\right)$ had a relatively higher influence on NPP than either NRL $\left(R^{2}=0.627, p<0.05\right)$ or $\mathrm{AH}\left(R^{2}=0.591, p<0.05\right)$. There were no significant relationships of NPP with climate or human activity in Xigaze and Ngari.
As shown in Fig. 4, climate factors and human activity explain $80.1 \%$ of the variation in NPP for Tibet. AMT and AMP, as independent variables, contributed $17.28 \%$ to NPP, which is lower than NA, NRL, and AH. These together contributed $24.73 \%$ (Fig. $4 \mathrm{a}$ ). Based on the results in Fig. $4 \mathrm{~g}$, the area that had a large change of NPP resulting from human activity is Ngari (36.38\%). Furthermore, the percentage of NA, NRL, and AH influence on NPP was only $5.57 \%$ and $7.39 \%$ in Lhasa and Xigaze, respectively. The contributions of climate factors and human activity were more than $50 \%$, apart from Lhasa and Xigaze. In fact, human activity was higher than climate factors for explaining the NPP dynamic in regions such as Shannan, Nagqu, Nagri, and Nyingchi.

For Tibet, annual mean precipitation and annual mean temperature have negative and positive effects on NPP, respectively, and the distribution of human activity is unbalanced. It is therefore necessary to analyze the effects of climate and human activity on the variations

Table 2. The correlation coefficient between NPP, AMT, AMP, NA, NRL, and AH in zones from 2000 to 2012.

\begin{tabular}{|c|c|c|c|c|c|c|c|c|}
\hline $\operatorname{NPP}\left(\mathrm{g} \mathrm{C} \mathrm{m}^{-2} \mathrm{a}^{-1}\right)$ & Tibet & Lhasa & Qamdo & Shannan & Xigaze & Nagqu & Ngari & Nyingchi \\
\hline $\operatorname{AMT}\left({ }^{\circ} \mathrm{C}\right)$ & $0.65^{*}$ & $0.61 *$ & $0.70 * *$ & $0.65^{*}$ & 0.14 & $0.69 * *$ & 0.29 & $0.66^{*}$ \\
\hline $\mathrm{AMP}(\mathrm{mm})$ & $0.69 * *$ & $0.56^{*}$ & 0.47 & $0.62 *$ & 0.14 & $0.60^{*}$ & 0.17 & $0.60 *$ \\
\hline NA ( $10^{4}$ heads $)$ & 0.14 & 0.29 & 0.19 & 0.27 & 0.14 & 0.52 & 0.25 & $0.78^{* *}$ \\
\hline NRL (person) & $0.63^{*}$ & 0.53 & $0.63 *$ & $0.72 * *$ & 0.25 & $0.75 * *$ & 0.48 & $0.59 *$ \\
\hline $\mathrm{AH}\left(10^{4}\right.$ yuan $)$ & 0.53 & 0.43 & $0.59 *$ & 0.47 & 0.23 & $0.62 *$ & 0.50 & $0.56^{*}$ \\
\hline
\end{tabular}

"Significance at 0.05 level, ${ }^{* *}$ Significance at 0.01 level 


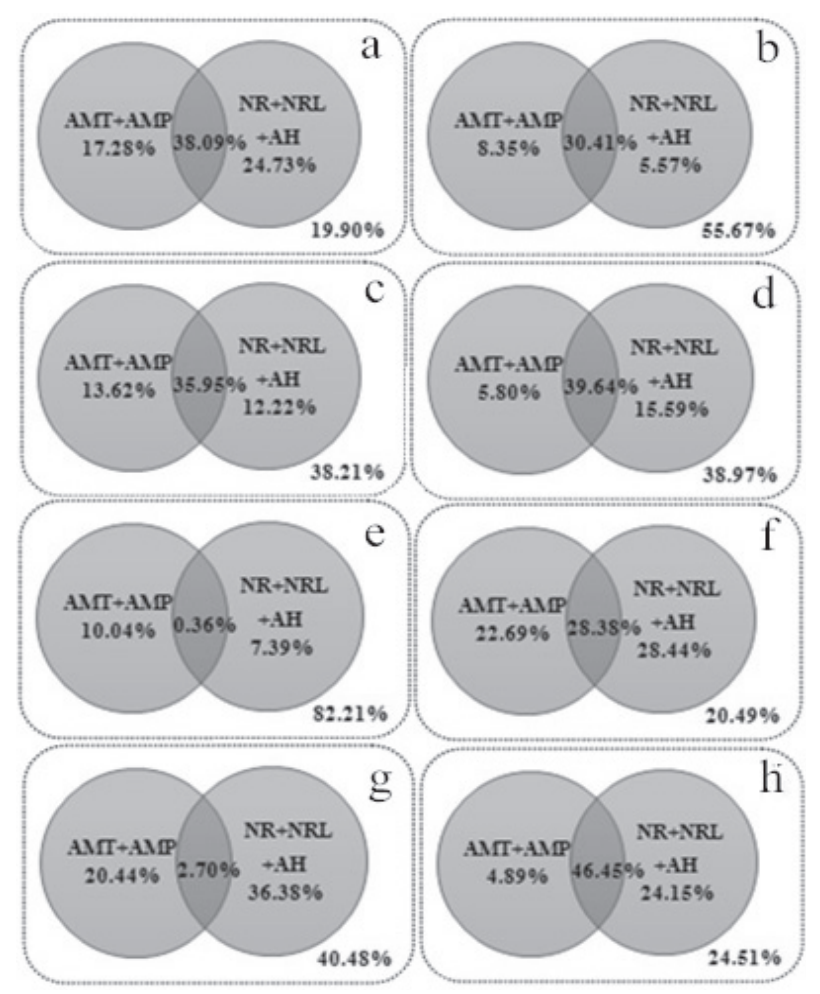

Fig. 4. Venn diagram of the contributions of climate factor and human factors to NPP. Contributions of NPP, AMT, AMP, NA, NRL, and AH to the spatial pattern of NPP across Tibet a), Lhasa b), Qamdo c), Shannan d), Xigaze e), Nagqu f), Ngari g), and Nyingchi h).

in NPP throughout different administrative divisions. It is worth noting that the number of animals did not have a significant impact on vegetation in Lhasa, which has a large population. However, a significant positive correlation was found between NRL, AH, and vegetation east of Xigaze. In contrast with evidence showing that vegetation resources are threatened by human population growth [6], a larger population might use vegetation resources more efficiently.

A close connection exists between vegetation and human activity $[34,35]$. Furthermore, the impact of the percentage of human activity on NPP did not increase human-activity density such as in Lhasa. Nevertheless, in Inner Mongolia, $89.6 \%$ of degraded areas can be explained by human activity [6]. Moreover, it cannot be denied that human activity makes up one of the most important factors involved in environmental change. On the other hand, human activity appears to have a greater impact on NPP than climate change (excluding plant growth) [36, 37].

However, it should be noted that the impact of climate and human activity on vegetation is complex, as other factors can affect vegetation. For example, vegetation affected by extreme weather benefits from the ecological reconstruction programs that have been organized from human activity [38]. If human activity such as industrialization and agricultural cultivation continues to increase, the grassland ecosystem is certain to be altered dramatically [39]. In such an eventuality, it will be necessary to take such measures as limiting grazing to minimize the overall impact due to a warming climate. Apart from climate factors and human activity, soil carbon and total nitrogen also contributed $21-46 \%$ for the NPP variation [40]. Of course vegetation self-rehabilitation should be considered in research studies [38].

\section{Conclusion}

Over the past 13 years it has become clear that NPP, AMT, NRL, and AH show an increasing trend. At the temporal scale, NPP increased gradually from northwest to southeast in Tibet, which is similar to AMP. The unbalanced phenomenon of NA, NAL, and $\mathrm{AH}$ was observed in Lhasa. In addition, the effect on NPP from human activity should not be ignored: for example, the effect of human activity on NPP accounted for $24.73 \%$ in Tibet - more than AMT and AMP with $17.28 \%$. In fact, the NPP was primarily affected by human activity in Nagqu, Ngari, and Nyingchi, and in Qamdo, Nagqu, and Ngari by climate factors.

It seems likely that the effects of human activity will increase with population growth and urbanization. In the near future, controlling population growth is vital for sustainable growth. What is more, fencing is the most important factor for vegetation recovery, which protects the degraded grassland in desert steppe zones. Thus, ecosystem circulation would improve and influence the atmosphere variation at the micro scale. Further studies should be conducted regarding grazing styles and the distribution of residence zones, and effective measurements (such as reasonable grassland controls) should be considered for grazing and improved NPP sustainability.

\section{Acknowledgements}

We would like to thank the China Meteorological Data Sharing Service System. This research was funded by the National Natural Science Foundation of China (No. 41501057), the West Light Foundation of the Chinese Academy of Sciences, and the Open Fund of the Key Laboratory of Mountain Surface Processes and Ecoregulation.

\section{References}

1. GULI-JIAPAE R., LIANG S.L., YI Q.X., LIU J.P. Vegetation dynamics and responses to recent climate change in Xinjiang using leaf area index as an indicator.Ecological Indicators. 58, 64-, 2015.

2. WANG G.X., BAI W., LI N., Hu H. Climate changes and its impact on tundra ecosystem in Qinghai-Tibet Plateau, China. Climatic Change. 106, 463, 2011.

3. LIU J., KANG S., GONG T., LU A. Growth of a highelevation large inland lake, associated with climate change and permafrost degradation in Tibet.Hydrology and Earth System Sciences. 14, 481, 2010. 
4. DHITAL D., YASHIRO Y., OHTSUKA T., NODA H., SHIZU Y., KOIZUMI H. Carbon dynamics and budget in a Zoysia japonica grassland, central Japan.Journal of Plant Research. 123 (4), 519, 2010.

5. HAN Q.F., LUO G.P., LI C.F., YE H., CHEN Y.L. hen. Modeling grassland net primary productivity and wateruse efficiency along an elevational gradient of the Northern Tianshan Mountains.Journal of Arid Land 5 (3), 354, 2013.

6. PIAO S.L., MOHAMMAT A., FANG J.Y., CAI Q., FENG J.M. NDVI-based increase in growth of temperate grasslands and its responses to climate changes in China.Global Environmental Change-Human and Policy Dimensions $\mathbf{1 6}$ (4), 340, 2006.

7. COMBOURIEU-NEBOU T., NATHALI E., ADELE BERTIN I., ELDA RUSSO-ERMOL I. Climate changes in the central Mediterranean and Italian vegetation dynamics since the Pliocene.Review of Palaeobotany and Palynology 218, 127, 2015.

8. SUN W.Y., SONG X.Y., MU X.M., GAO P., WANG F., ZHAO G.J. Spatiotemporal vegetation cover variations associated with climate change and ecological restoration in the Loess Plateau.Agricultural and Forest Meteorology. 209210, 87, 2015.

9. LI H.W., YANG X.P. Temperate dryland vegetation changes under a warming climate and strong human intervention With a particular reference to the district Xilin Gol, Inner Mongolia, China. CATENA. 119, 9, 2014.

10. WANG J., RICH J.P., PRICE K.P. Temporal responses of NDVI to precipitation and temperature in the central Great Plains, USA.Remote Sensing. 24, 2345, 2003.

11. CHU D., LU T., ZHANG T. Zhang.Sensitivity of normalized difference vegetation index (NDVI) to seasonal and interannual climate conditions in the Lhasa area, Tibetan plateau, China.Arctic Antarctic and Alpine Research. 39 (4), 635, 2007.

12. JIAN P., LIU Z.H.,LIU Y.H., WU J.S., HAN Y.N. Trend analysis of vegetation dynamics in Qinghai - Tibet Plateau using Hurst Exponent. Ecological Indicators. 14 (1), 28, 2012.

13. HIROTA M., KAWASA K., HU Q.W., KATO T., TANG Y.H., MO W.H., CAO G.M., MOARIKO S. Net primary productivity and spatial distribution of vegetation in an alpine wetland, Qinghai-Tibetan Plateau.Limnology. 8 (2), $161,2007$.

14. LUO T.X., PAN Y.D., OUYANG H., SHI P.L., LUO J., YU Z.L., LU Q. Leaf area index and net primary productivity along subtropical to alpine gradients in the Tibetan Plateau. Global Ecology and Biogeography. 13 (4), 345, 2004.

15. LUO T.X., LI W.H., ZHU H.Z.Estimated biomass and productivity of natural vegetation on the Tibetan Plateau. Ecological Applications. 12 (4), 980-, 2002.

16. MAO D.H., LUO L., WANG Z.M., ZHANG C.H., REN C.Y. Variations in net primary productivity and its relationships with warming climate in the permafrost zone of the Tibetan Plateau.Journal of Geographical Sciences. 25 (8), 967, 2015.

17. GAO Y.H., ZHOU X., WANG Q., WANG C.Z., ZHAN Z.M., CHEN L.F., YAN J.X., QU R. Vegetation net primary productivity and its response to climate change during 2001-2008 in the Tibetan Plateau.Science of the Total Environment. 444, 356, 2013.

18. KRAMER A., HERZSCHUH U., MISCHKE S., ZHANG C.J. Late Quaternary environmental history of the southeastern Tibetan Plateau inferred from the Lake Naleng non-pollen palynomorph record.Vegetation History and Archaeobotany. 19 (5-6), 453, 2010.

19. MIEHE GEORG., MIEHE SABINE., KAISER KNUT.,
REUDENBACH CHRISTOPH., BEHRENDES LENA., LA DUO.,SCHLUTZ FRANK. How old is pastoralism in Tibet? An ecological approach to the making of a Tibetan landscape. Palaeogeography Palaeoclimatology Palaeoecology. 276 (14), 130, 2009.

20. OMUTO C.T., VARGAS R.R., ALIM M.S., PARON P. Mixed-effects modelling of time series NDVI-rainfall relationship for detecting human-induced loss of vegetation cover in drylands.Journal of Arid Environments. 74 (11), 1552, 2010.

21. GAO Q.Z., WAN Y.F., XU H.M., LI Y., JIANGCUN W.Z., BORJIGIDAI ALMAZ. Alpine grassland degradation index and its response to recent climate variability in Northern Tibet, China.Quaternary International. 226 (1-2), 143, 2010.

22. WU S.H., YIN Y.H., ZHAO D.S., ZHAO M., HUANG M., SHAO X.M., DAI E.F. Impact of future climate change on terrestrial ecosystems in China.International Journal of Climatology. 30 (6), 866, 2010.

23. LI L., YANG S., WANG Z.Y., ZHU X.D., TANG H.Y. Evidence of Warming and Wetting Climate over the QinghaiTibet Plateau.Arctic, Antarctic, and Alpine Research. 42, 449, 2010.

24. LIU W., GUO Q.H., WANG Y.X. Temporal-spatial climate change in the last 35 years in Tibet and its geo-environmental consequences.Environ Geol. 54, 1747, 2008.

25. SUN J., CHENG G.W., LI W.P. Meta-analysis of relationships between environmental factors and aboveground biomass in the alpine grassland on the Tibetan Plateau.Biogeosciences. 10 (3), 1707, 2013.

26. ZHANG Y.L., QI W., ZHOU C.P., DING M.J., LIU L.S., GAO J.G., BAI W.Q., WANG Z.F., ZHENG D. Spatial and temporal variability in the net primary production of alpine grassland on the Tibetan Plateau since 1982.Journal of Geographical Sciences. 24 (2), 269, 2014.

27. POST E., FORCHHAMMER M.C., BRET-HARTE M.S., CALLAGHAN T.V., CHRISTENSEN T.R., ELBERLING B., FOX A.D., GILG O., HIK D.S., HOYE T.T., LMS R.A., JEPPESON E., KLEIN D.R., MADSEN J., MCGUIRE A.D., RYSGAARD S., SCHINDLER D.E., STIRLING I., TAMSTORF P., TYLER N.J.C., VAN DER WAL R., WELKER J., WOOKEY P.A., SCHMIDT N.M., AASTRUP P. Ecological Dynamics Across the Arctic Associated with Recent Climate Change. Science. 325 (5946), 1355, 2009.

28. KRAUSMANN F., ERB K.H., GINGRICH S., HABERL H., BONDEAU A., GAUBE V., LAUK C., PLUTZAR C., SEARCHINGER T.D. Global human appropriation of net primary production doubled in the 20th century.Proceedings of the National Academy of Sciences of the United States of America. 110 (25), 10324, 2013.

29. LIU Y.X., WANG Y.L., PENG J., DU Y.Y., LIU X.F., LI S.S., ZHNAG D.H. Correlations between Urbanization and Vegetation Degradation across the World's Metropolises Using DMSP/OLS Nighttime Light Data.Remote Sensing. 7 (2), 2067, 2015.

30. SUN J., WANG X.D., CHENG G.W., WU J.B., HONG J.T., NIU S.L. Effects of Grazing Regimes on Plant Traits and Soil Nutrients in an Alpine Steppe, Northern Tibetan Plateau. Plos One. 9 (9), 2014.

31. ZEGEYE HAILEAB., TEKETAY DEMEL., KELBESSA ENSERMU. Diversity, regeneration status and socioeconomic importance of the vegetation in the islands of Lake Ziway, south-central Ethiopia.Flora - Morphology, Distribution, Functional Ecology of Plants. 201 (6), 483, 2006.

32. DING M.J., ZHANG Y.L., SUN X.M., LIU L.S., WANG Z.F., BAI W.Q. Spatiotemporal variation in alpine grassland 
phenology in the Qinghai-Tibetan Plateau from 1999 to 2009. Chinese Science Bulletin. 58 (3), 396, 2013.

33. ZHANG G.L., DONG J.W., ZHANG Y.J., XIAO X.M. Reply to Shen et al., No evidence to show nongrowing season NDVI affects spring phenology trend in the Tibetan Plateau over the last decade.Proceedings of the National Academy of Sciences of the United States of America. 110 (26), E2330, 2013.

34. ZHANG W.X., MILLER P.A., SMITH B., WANIA R., KOENIGK T., DOSCHER R. Tundra shrubification and treeline advance amplify arctic climate warming: results from an individual-based dynamic vegetation model. Environmental Research Letters. 8 (3), 2013.

35. TIAN H.J., GAO C.X., CHEN W., BAO S.N., YANG B., MYNENI RANGA B. Response of vegetation activity dynamic to climatic change and ecological restoration programs in Inner Mongolia from 2000 to 2012. Ecological Engineering. 82, 276, 2015.

36. REVELLES J., CHO S., IRIARTE E., BURJACHS F., VAN GEEL B., PALOMO A., PIQUE R., PENA-CHOCARRO L., TERRADAS X. Mid-Holocene vegetation history and Neolithic land-use in the Lake Banyoles area (Girona, Spain).
Palaeogeography, Palaeoclimatology, Palaeoecology. 435, 70, 2015.

37. VAN DER LINDEN M., VICKERY E., CHARMAN DAN J., BROEKENS P., VAN GEEL B. Vegetation history and human impact during the last 300 years recorded in a German peat deposit.Review of Palaeobotany and Palynology. 152 (3-4), 158, 2008.

38. WANG J., WANG K.L., ZHANG M.Y., ZHANG C.H. Impacts of climate change and human activities on vegetation cover in hilly southern China. Ecological Engineering. 81, 451, 2015.

39. ZHANG H., WANG Z.F., ZHANG Y.L., DING M.J., LI L.H. Identification of traffic-related metals and the effects of different environments on their enrichment in roadside soils along the Qinghai - Tibet highway. Science of The Total Environment. 521-522, 160, 2015.

40. SHEVYRNOGOV A., VYSOTSKAYA G., SUKHININ A.,FROLIKOVA O., TCHERNETSKY M. Results of analysis of human impact on environment using the time series of vegetation satellite images around large industrial centers. Advances in Space Research. 41 (1), 36-, 2008. 